MARKETING AND BRANDING
RESEARCH $\begin{gathered}\text { INDUSTRIAL } \\ \text { MANAGEMENT } \\ \text { INSTITUTE }\end{gathered}$

\title{
The influence of social media behavior of university students in Lebanon on their purchasing habits: The mediating effect of e-Word-of-Mouth
}

\author{
Annelie Moukaddem Baalbaki, Nadia Jiryes Azzam*, Abdul-Nasser El-Kassar \\ Lebanese American University, Beirut, Lebanon
}

\begin{abstract}
Keywords:

Social Media,

Electronic Word-of-

Mouth, Consumer's

Purchase Decision

Correspondence:

nadia.azzam@lau.edu.lb

Consumers are increasingly seeking information through Social Media (SM) platforms to guide their future purchasing decisions. Electronic Word-of-Mouth (eWOM) through the ever popular SM, especially among young consumers, can have great influence on consumers' perception and buying intention. In this paper, we analyze consumer behavior of university students in Lebanon through studying the effect of their SM habits and impact of eWOM on their purchase habits and intentions. SM considered Facebook, Twitter, Instagram, and Snapchat; eWOM refers to recommendations by friends and experts. A conceptual model is presented and tested empirically taking advantage of data collected from different universities. The model tests the mediating effects of eWOM on the relationship between SM usage of students on their purchase intentions of products discussed on SM platforms by friends and experts. A sample of 200 university students in Lebanon who responded to an online survey is used to examine proposal model. Partial least square structural equation modeling (PLS-SEM) through the Smart PLS3 software is used to analyze survey data. The preliminary results support the hypothesis that the more time students spend on SM, the more likely they will be influenced by e-WOM by friends and experts which in turn might influence their buying intentions.
\end{abstract}

(C)AIMI Journals

\section{Introduction}

Today consumers are faced with a lot of options and opportunities to satisfy their needs. They are in a constant dilemma in selecting what they need as they are offered a tremendous variety of products and services from different brands, with different features, in different stores, and at different prices. Nowadays, this diversity of options made consumers more careful in their purchase decisions. According to the buying decision process model (CDP), when consumers 
have a strong need, they search for information and evaluate the various alternatives before buying a product/service to minimize the post purchase cognitive dissonance that results from any inappropriate choice (Blackwell, Miniard, \& Engel, 2006). The more time they have and the more important the purchase is, the more they will undertake extensive search from various sources.

Few decades ago, information search was mainly limited to the consumers' individual knowledge and experience, input collected from store visits, as well as feedback -better known as word-of-mouth (WOM) - from family, friends, and neighbors. Consumers have more confidence in word-of-mouth as they consider it more reliable than companies' ads and promotional efforts (Mohammadi, Khabiri, \& Barari, 2013). Marketers can even depend on WOM communication as a reliable competitive advantage tool (Mohammadi, Khabiri, \& Barari, 2013). In this respect, Facebook, Instagram, and other social platforms -that were initially introduced aiming just to bring people together - have become today a highly useful medium for both consumers and marketers: These platforms and the resulting eWOM are on top of the list of information search sources for both parties. Marketers get detailed consumers' insight about their interests and preferences from various platforms (Schiffman \& Wisenblit, 2015). They base their marketing strategies on these insights. On a similar note, before making any purchase decision, consumers in general and Millennials in particular rely on feedback they get from social media platforms and blogs much more than they rely on TV news and ads in magazines. Today social media is considered by far as their primary source for searching and learning about products, special deals, and to receive updated shopping news.

\section{The Literature Review}

Strauss and Frost (2013) defined social media as webpages generated by internet users. These webpages are an open opportunity for social networking and discussions. A wide variety of social media platforms are being created online and attract much more users than companies' websites and other traditional media sites. Today, online social networks have tremendously facilitated the spreading and sharing of data and feedback over the Internet. This explains why consumers rely to a great extent on SM in their search for information about products/services they intend to buy.

Social media websites have led to the development of eWOM chats and gave consumers the opportunity to discuss and exchange feedback on products/services they have experienced (Erkan \& Evans, 2016). According to Hennig-Thurau, Gwinner, Walsh, and Gremler (2004), eWOM consists of a series of data related to a product or a brand that individuals and companies can easily access to via the Internet. Following this, eWOM is a channel allowing individuals to provide their feedback on their purchase experience (Lerrthaitrakul \& Panjakajornsak, 2014). As the data is provided by current, potential or ex-customers, the outcome could be positive or negative (Hennig-Thurauet al., 2004.). Thus, the positive feedback would be considered as a good advice in favor of the specific product/service, while the negative feedback is a complaint, criticism or undesirable recommendation (Akbari, Kazemi, \& Haddadi, 2016).

Customers who are satisfied with a brand, product, service, or event draw progressive awareness of others to the item (Goyette, Richard, Bergeron, \& Marticotte, 2013). It is worth 
noting that one person tells another and each will tell more and more others. In further analysis, WOM communication has been allocated into 9 different levels depending on its negative/neutral/positive effect on consumers (Silverman, 2001). The classification starts with the worst level where people speak bad about products and inhibit using them (Negative Fourth Level) through the neutral level where people use products but do not comment about it (Zero Level) ending with the extreme positive level where professionals, influencers, celebrities, and elite customers speak positively about the product (Positive Fourth Level).

Since the era of Web 2.0, consumers discuss and share their opinion, feedback, and recommendations on various brands and products they have experienced through various social network web platforms such as web blogs, chat rooms, and review sites. Recently, the classical way of passing messages through word-of-mouth has become electronic, referred to today as eWOM (Lerrthaitrakul \& Panjakajornsak, 2014).Consumers today rely to a large extend on eWOM by friends, experts, and celebrities before making up their mind about a specific purchase. Consumers are highly influenced by messages they get through various blogs, review websites, discussion forums, and the like.

As a matter of fact, many researchers have emphasized the impact of eWOM on consumer's purchase intentions (PI). In their research, Schivinski and Dabrowski (2016) indicated that PI may be viewed as a variable psychologically connecting attitude and behavior. They studied the impactSM communication has on position towards the brand and the resulting influence on consumers' PI. Erkan and Evans (2016) analyzed factors that positively affect individuals' buying intentions. Results showed that both the quality of information provided by eWOM and the consumers' attitude and beliefs toward eWOM are positively related to PI. Consumers feel more at ease if, before they buy, they can have access to data and experience other customers went through (Erkan \& Evans, 2016).

Various researchers are interested in investigating the effect of eWOM on consumers' buying behavior and purchases. Prospective consumers (Millennials in particular) can easily access to a wide variety of online sources provided through several eWOM platforms. They can retrieve data from shopping websites, blogs, discussion platforms and the like. Through various social media websites and eWOM platforms, individuals can connect with their peers (Erkan \& Evans, 2016).In this respect, getting information and experience feedback from friends, experts, and celebrities has become easy to access. EWOM has evolved to become a vital influencer in learning, understanding, and mainly evaluating consumers' products/services before buying them.

Millennials worldwide look for an easy and quick way of collecting information that will help them learn more about products before buying them and avoid (or at least decrease) any post purchase cognitive dissonance. Since word-of-mouth - as a source of information- is easy, quick and considered commercially unbiased (Akbari, Kazemi, \& Haddadi, 2016), Millennials rely more on WOM and eWOM and social media platforms. As university students in Lebanon have regular access to the Internet they are increasingly referring to social media and eWOM for their input.

Improvements and widespread of the Internet and the easy access to various information sites have led to the creation of a multitude of Social Media platforms and encouraged the widespread of eWOM. Researchers were interested to analyze their effect and how different 
platforms and eWOM could influence consumers' decision process and purchase intentions. In their research, Lee and Youn (2009) found out that consumers are better connected and share information more easily via the increased number of eWOM platforms. As discussions on eWOM could be anonymous, people are more willing to share their experiences and opinions and provide their feedback. This justifies the abundance of eWOM messages. Credibility of the multitude of eWOM messages and reviews from the numerous platforms was analyzed in various research. Among others, Doh and Hwang (2009) studied the effect of negative messages. They concluded that few negative messages positively affect the attitude of the consumers toward a Website and will enhance the credibility of eWOM messages. Unfavorable messages could damage a company's brand or product reputation; however, negative information, found in eWOM, has been proven to be resourceful in promoting both credibility and attitude deemed positive towards the website being viewed. They also concluded that involvement and prior knowledge play a positive role in consumers' decision in some situations. In this respect, the research done by Gunawan and Huarng (2015) realized that the individual's purchase intentions to buy virally marketed products are positively influenced by their subjective norms.

Not much research was carried to test the effect of time spent on Social Media on the buying intentions of Millennials. This is why this research was implemented to analyze the effect of SM and eWOM on purchase decisions of university students in Lebanon and to clarify if time spent on these platforms has any effect on their purchase intentions and the role of eWOM on that.

\section{The Study}

The proposed model is depicted in Figure 1.

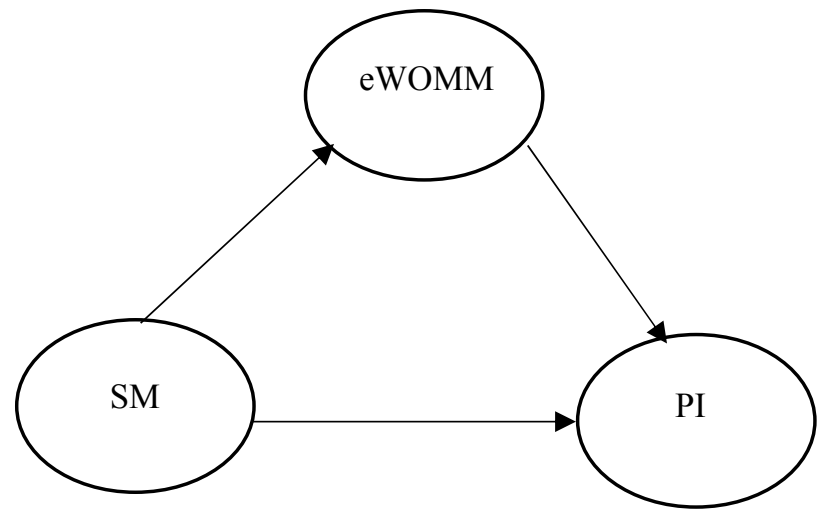

Figure 1. The proposed model

\section{Research Questions and Research Hypotheses}

The following research questions guided the study:

- What is the influence of Social Media platforms on purchase intentions of university students in Lebanon?

- What is the influence of eWOM on purchase intentions of university students in Lebanon?

- If students are spending more time on SM, will they be more affected by eWOM?

- Can eWOM be a mediator between Social Media behavior and Purchase Intentions? 
In order to examine the research questions stated above, the following hypotheses are formulated:

$\mathbf{H}_{1}$ : The more time university students spend on SM, the more likely they are positively influenced by eWOM.

$\mathbf{H}_{2}$ : University students Purchase Intentions (PI) are positively influenced by the time they spend on Social Media

$\mathbf{H}_{3}$ : University students Purchase Intentions (PI) are positively influenced by eWOM.

$\mathbf{H}_{4}$ : eWOM mediates the relationship between SM behavior and PI.

\section{Method}

An online questionnaire was sent to 550 university students in Lebanon. Out of the 221 completed questionnaire, 200 were found useful and were used to examine the proposal model. Following this, $52.8 \%$ of the respondents were females. The majority of the respondents were at the freshman or sophomore level (53.8\%).

In addition to the demographic questions, the survey contained questions related to the usage of social media, eWOM and purchase intention of a product or service, see Appendix A. Partial least square structural equations modeling (PLS-SEM) through the Smart PLS3 software was used to analyze survey data. The latent variables SM was measured using 3 items based on the frequency of social media usages. Twitter was excluded since a large percentage of respondents indicated that they do not use it. Also, recommendations by friends were found to have the least effects. Hence, eWOM and PI were measured using 6 items and 2 items, respectively, based on recommendations by experts and celebrities. The structural model results are shown in Figure 2.

The bootstrapping method revealed that all items used to measure the three construct of the structural models had significant loading higher than 0.7. The latent constructs' factor loadings are depicted in Figure 2.

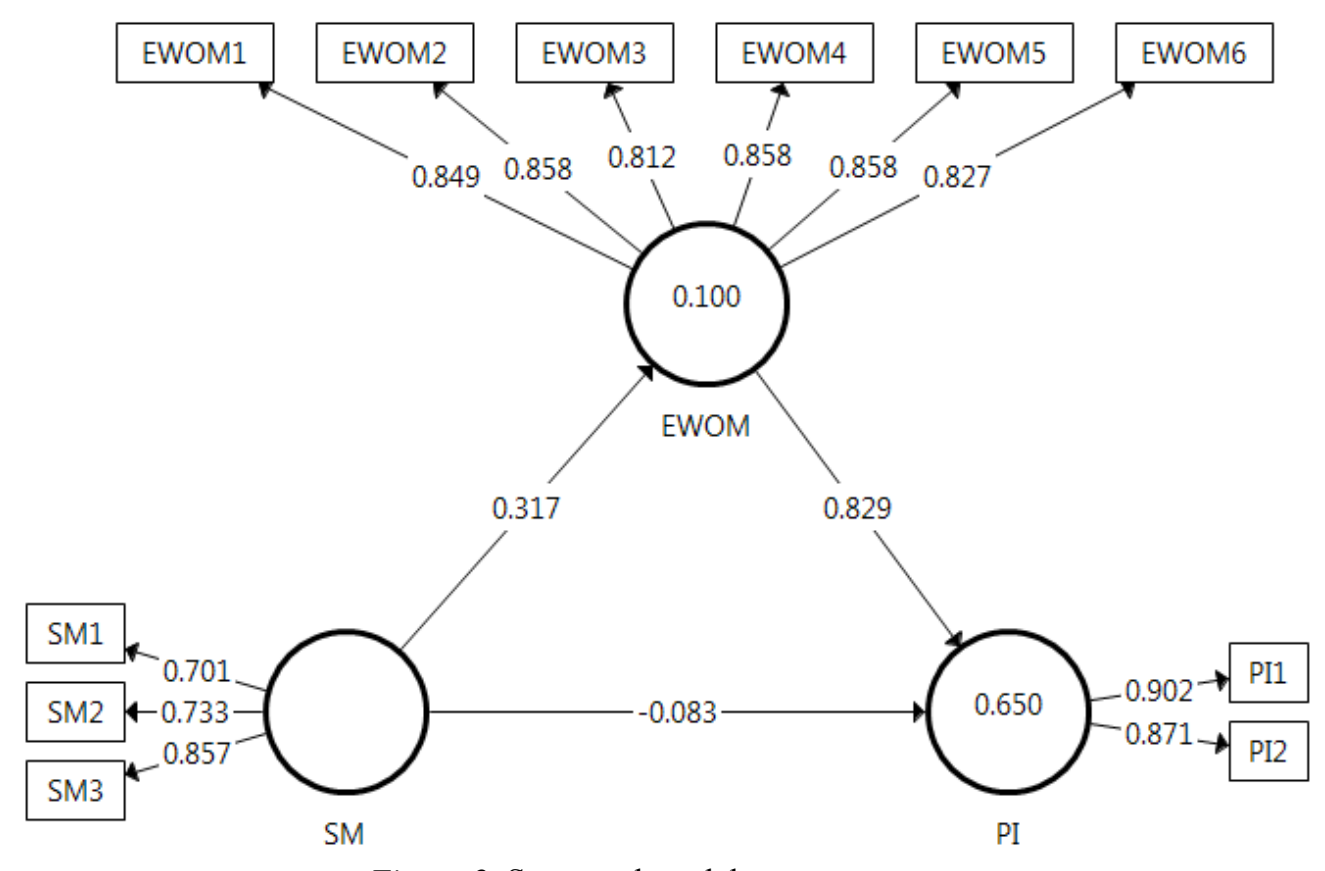

Figure 2. Structural model 


\section{Results}

The constructs reliability and validity results are presented in Table 1 . They indicate that the measures used are reliable since all composite reliability values are above 0.8 . The average variance extracted (AVE) for each measure surpasses the recommended level of 0.5.

Table 1

Model Reliability

\begin{tabular}{ccc}
\hline Construct & Composite Reliability & AVE \\
\hline eWOM & 0.93 & 0.71 \\
PI & 0.88 & 0.78 \\
SM & 0.80 & 0.58 \\
\hline
\end{tabular}

As for the discriminant validity of the constructs, the results are displayed in Table 2. The scales' discriminant validity is supported since each value on the diagonal is larger than all values in its row or column.

Table 2

The Discriminant Validity of the Scales

\begin{tabular}{cccc}
\hline Construct & eWOM & PI & SM \\
\hline eWOM & 0.84 & & \\
PI & 0.80 & 0.88 & 0.76 \\
SM & 0.31 & 0180 & \\
\hline
\end{tabular}

The bootstrap method, with 5000 subsamples, was applied to test the significance of the path coefficients and the results are presented in Table 3.

Table 3

Path Coefficients Results

\begin{tabular}{lcccc}
\hline & Original Sample & Standard Deviation & T-Values & P-Values \\
\hline Direct Effects & & & & 0.00 \\
\hline eWOM $\rightarrow$ PI & 0.829 & 0.03 & 22.59 & 0.00 \\
$\mathrm{SM} \rightarrow$ eWOM & 0.31 & 0.05 & 5.98 & 0.09 \\
$\mathrm{SM} \rightarrow$ PI & -0.08 & 0.04 & 1.68 & 0.00 \\
\hline Indirect Effects & & & & 5.55 \\
\hline $\mathrm{SM} \rightarrow$ PI & 0.26 & 0.04 & & \\
\hline
\end{tabular}

The results of Table 3 revealed that hypothesis $\mathrm{H}_{1}$ is supported as the path coefficient between SM and eWOM is significant (coef. $=0.31$, p-value $=0.00$ ). This indicates that the more time university students spend on SM, the more they are positively influenced by eWOM. Also, $\mathrm{H}_{2}$ is not supported as the path coefficient between $\mathrm{SM}$ and eWOM is significant (coef. $=-0.08$, p-value $=0.09$ ). Hence, university students PI were not directly influenced by time spent on SM. Moreover, $\mathrm{H}_{3}$ is supported as the path coefficient between $\mathrm{SM}$ and eWOM is significant (coef. $=0.82$, p-value $=0.00$ ). Therefore, University students PI are significantly influenced by eWOM. Finally, $\mathrm{H}_{4}$ is supported as the path coefficient 
between SM and eWOM is significant (coef. $=0.26, \mathrm{p}$-value $=0.00$ ). These results indicate that eWOM fully mediates the relationship between SM behavior and PI. Hence, the results of the study show that the more time students spend on SM, the more likely they will be influenced by eWOM by friends and experts which in turn might influence their buying intentions. Accordingly, SM and eWOM are becoming essential marketing tools that should be used to help reach and influence university students.

\section{Discussion and Conclusion}

Based on the above research results, we recommend that companies operating in Lebanon and targeting university students strengthen their position and enhance their presence on various social media platforms. Today, SM and eWOM are opening a lot of opportunities for success. Companies should rely more on various SM platforms and eWOM to inform as well as motivating their target market to purchase their products. Research has proven that advertising and promoting company's image and its brands and products through SM and eWOM is highly beneficial.

On the other hand, companies should provide experts and celebrities' feedback on SM. In addition, companies should encourage consumers to provide ratings and reviews. For future research, we suggest extending the model to incorporate other elements of SM behavior such as trust in SM and eWOM messages, credibility of information posted, and the influence of positive versus negative posted messages.

Future research could also analyze whether the consumers' search for information on SM and eWOM will vary if the consumer's purchase decision is a first time buy, a straight rebuy or modified rebuy. We also suggest to develop a cross-cultural comparison between MENA region university students and their counterparts in Western Countries.

\section{References}

Akbari, M., Kazemi, R., \& Haddadi, M. (2016). Relationship marketing and word-of-mouth communications: Examining the mediating role of customer loyalty. Marketing and Branding Research, 3(1), 63-74.

Blackwell, R. D., Miniard, P. W., \& Engel, J. F. (2006). Consumer Behavior (10 ${ }^{\text {th }}$ ed.). Mason: Thomson South-Western.

Doh, S. J., \& Hwang, J. S. (2009). How consumers evaluate eWOM (Electronic Word-of-Mouth) messages. Cyber Psychology \& Behavior, 12(2), 193-197.

Erkan, I., \& Evans, C. (2016). The influence of eWOM in social media on consumers' purchase intentions: An extended approach to information adoption. Computer in Human Behavior, 61, 47-55.

Goyette, I., Richard, L., Bergeron, J., \& Marticotte, F. (2013). E-WOM scale: Word-of-Mouth measurement scale for eservice context. Canadian Journal of Administrative Sciences, 27(1), 5-23.

Gunawan, D. D., \& Huarng, K. H. (2015). Viral effects of social network and media on consumers' purchase intention. Journal of Business Research, 68(11), 2237-2241.

Hennig-Thurau, T., Gwinner, K. P., Walsh, G., \& Gremler, D. D. (2004). Electronic word-of-mouth via consumer-opinion platforms: What motivates consumers to articulate themselves on the Internet? Journal of Interactive Marketing, 18(1), $38-52$.

Lee, M., \& Youn, S. (2009). Electronic Word of Mouth (eWOM). International Journal of Advertising, 28(3), 473-499.

Lerrthaitrakul, W., \& Panjakajornsak, V. (2014). The impact of Electronic Word-of-Mouth factors on consumers' buying decision-making processes in the low cost carriers: A conceptual framework. International Journal of Trade, Economics \& Finance, 5(2), 142-146. 
Mohammadi, R., Khabiri, M., \&Barari, M. (2013). The benefits of establishing a relationship with the customer and its effect on positive word-of-mouth communication: A case study of customers of pools in Tehran. Journal of Sports Management Studies, 19, 205-220.

Schiffman, L., \& Wisenblit, J. (2015). Consumer Behavior (1 $1^{\text {th }}$ ed.) Pearson Education.

Schivinski, B., \& Dabrowski, D. (2016). The effect of social media communication on consumer perceptions of brands. Journal of Marketing Communications, 22(2), 189-214.

Silverman, G. (2001). The secrets of word-of-mouth marketing: How to trigger exponential sales through runaway word-ofmouth. New York: AMACOM.

Strauss, J., \& Frost, R. (2013). E-marketing international edition ( $7^{\text {th }}$ ed.). USA: Prentice Hall. 